\title{
Operative treatment of tetralogy of Fallot with concomitant correction of anomalous origin of the left pulmonary artery from Kommerell's diverticulum
}

\author{
Jacek Juscinski ${ }^{1}$, Ireneusz Haponiuk ${ }^{1,2}$, Maciej Chojnicki ${ }^{1}$, Mariusz Steffens ${ }^{1}$, Aneta Szofer-Sendrowska ${ }^{1}$, \\ Radoslaw Jaworski ${ }^{1}$, Ewelina Kwasniak ${ }^{1}$, Pawel Żelechowski ${ }^{3}$ \\ ${ }^{1}$ Department of Pediatric Cardiac Surgery, Pomeranian Centre of Traumatology in Gdansk, Poland \\ ${ }^{2}$ Chair of Physiotherapy, Gdańsk University of Physical Education and Sport, Poland \\ ${ }^{3}$ Department of Cardiac Surgery, Medical University of Gdansk, Poland
}

Kardiochirurgia i Torakochirurgia Polska 2014; 11 (3): 336-338

\begin{abstract}
Anomalies in development of the pulmonary valve, pulmonary trunk and peripheral pulmonary arteries are typical accompanying pathologies in patients with tetralogy of Fallot (ToF). Demanding for diagnostics and borderline for treatment is a condition colloquially called "discontinuous pulmonary arteries", while the main branches are supplied with systemic blood from the ascending aorta, aortic arch or descending thoracic aorta. We present a case of a one-year-old girl with ToF and anomalous origin of the left pulmonary artery (LPA) from Kommerell's diverticulum who underwent two-stage surgical therapy with the support of interventional cardiology.

We conclude that early diagnosis of discontinuous pulmonary artery is crucial for choosing the optimal operative strategy. In our opinion, simultaneous anatomic intracardiac correction with direct pulmonary reconstruction seems reasonable and effective, particularly when the result is achieved after joint efforts of cardiac surgery and interventional cardiology.

Key words: tetralogy of Fallot, pulmonary arteries discontinuity, Kommerell diverticulum, anomalous origin of left pulmonary artery.
\end{abstract}

\section{Introduction}

Anomalies and underdevelopment of the pulmonary valve, pulmonary trunk and pulmonary arteries are typical accompanying anomalies in individuals with complex forms of tetralogy of Fallot (ToF). Most patients in the group present different degrees of hypoplasia of one or both pulmonary arteries. Specific rare pulmonary malformations are so-called "discontinuous pulmonary arteries" with their anomalous origin from the ascending or descending aorta, as well as aortic arch vessels. Clinical presentation of such pathologies could be a challenge for routine diagnostics, therapeutic strategy plans, and the final results.

\section{Streszczenie}

Anomalie rozwoju zastawki płucnej, pnia płucnego i tętnic płucnych są typowymi patologiami towarzyszącymi tetralogii Fallota. Wymagający diagnostycznie i terapeutycznie jest wariant anatomiczny z brakiem ciągłości tętnic płucnych.

W pracy przedstawiono przypadek rocznej dziewczynki z tetralogią Fallota i nieprawidłowym odejściem lewej gałęzi tętnicy płucnej od uchyłka Kommerella, która została poddana dwuetapowemu leczeniu kardiochirurgicznemu z wykorzystaniem technik kardiologii inwazyjnej.

Autorzy uważają, że wczesna diagnoza braku ciągłości tętnic płucnych jest kluczowa dla wyboru optymalnej strategii operacyjnej. W opinii autorów skojarzona anatomiczna korekcja wady wewnątrzsercowej z bezpośrednią rekonstrukcją naczyń płucnych wydaje się rozsądnym i skutecznym leczeniem u pacjentów z tetralogią Fallota i brakiem ciągłości tętnic płucnych. Stowa kluczowe: tetralogia Fallota, uchyłek Kommerella, wady wrodzone.

We present a case of a one-year-old girl with ToF and the discontinuation of pulmonary arteries, with anomalous origin of the left pulmonary artery (LPA) from Kommerell's diverticulum, who underwent successful, although troublesome, two-stage surgical treatment in cooperation with interventional cardiology.

\section{Case report}

A one-year-old $10 \mathrm{~kg}$ body weight girl was urgently admitted to the Department of Pediatric Cardiac Surgery, Mikolaj Kopernik Hospital in Gdańsk (Poland), with the initial diagnosis of ToF. Because of the emergency setting and

Address for correspondence: Radosław Jaworski, Department of Pediatric Cardiac Surgery, Pomeranian Centre of Traumatology in Gdansk, Nowe Ogrody 1-6, 80-803 Gdańsk, phone: +48 602243 114, e-mail: radicis@go2.pl 


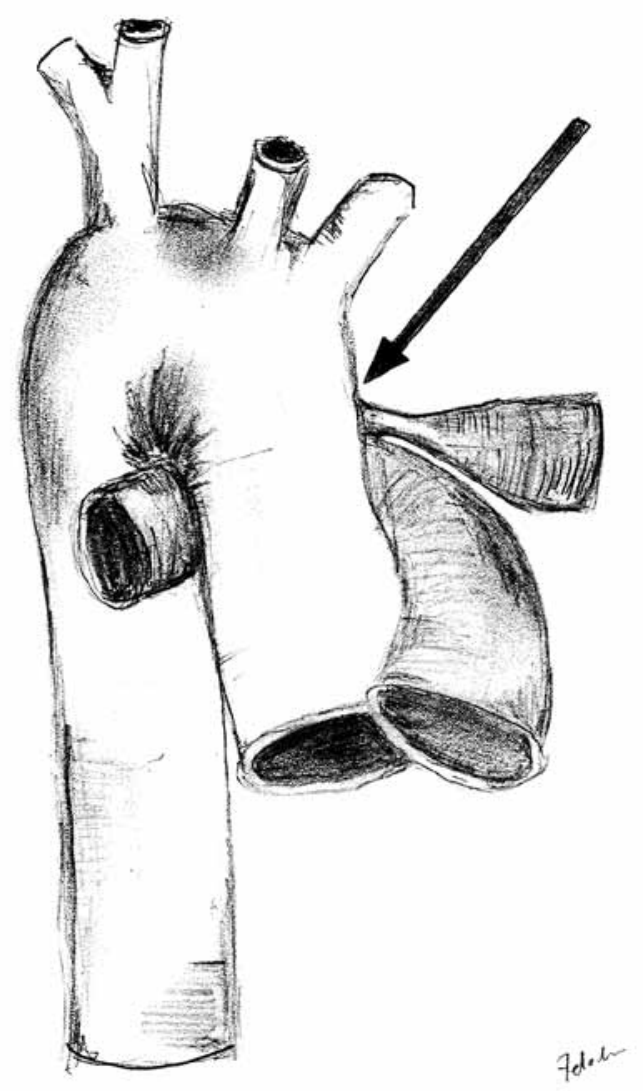

Fig. 1. Abnormal origin of left pulmonary artery (arrow) from Kommerell's diverticulum

clinical manifestation of extensive cyanosis with average peripheral saturation of $70 \%$, a typical right-sided BlalockTaussig (BT) shunt (Gore-Tex $5 \mathrm{~mm}$ ) was done in a routine thoracotomy fashion.

After meticulous transthoracic echocardiography (TTE) examination there was an evident disproportion in diameter between pulmonary arteries (the right pulmonary artery diameter was bigger), and the anatomical position of the LPA was not well presented by means of ultrasound diagnostics. On the first postoperative day, right-sided hydrothorax was evacuated by chest tube insertion. During the early postoperative period, despite competent BT shunt function, persistent cyanosis with mild dyspnea was observed.

A month later the patient was admitted again to our institution from the referring hospital because of increasing dyspnea, $\mathrm{O}_{2}$ sat. below $80 \%$, and the symptoms of the heart failure with fluid retention in the right thorax. During cardiac catheterization abnormal origin of the LPA from Kommerell's diverticulum and the patent arterial duct (PDA) was discovered [1], and discontinuous pulmonary arteries were confirmed (Fig. 1). Blood flow in the BT shunt remained satisfactory, while the anomalous LPA origin from Kommerell's diverticulum and PDA was obstructed. Because of LPA ostial stenosis, gentle percutaneous balloon angioplasty was performed to give load to the left lung and thus stabilize the child before final operative correction. In the next two days

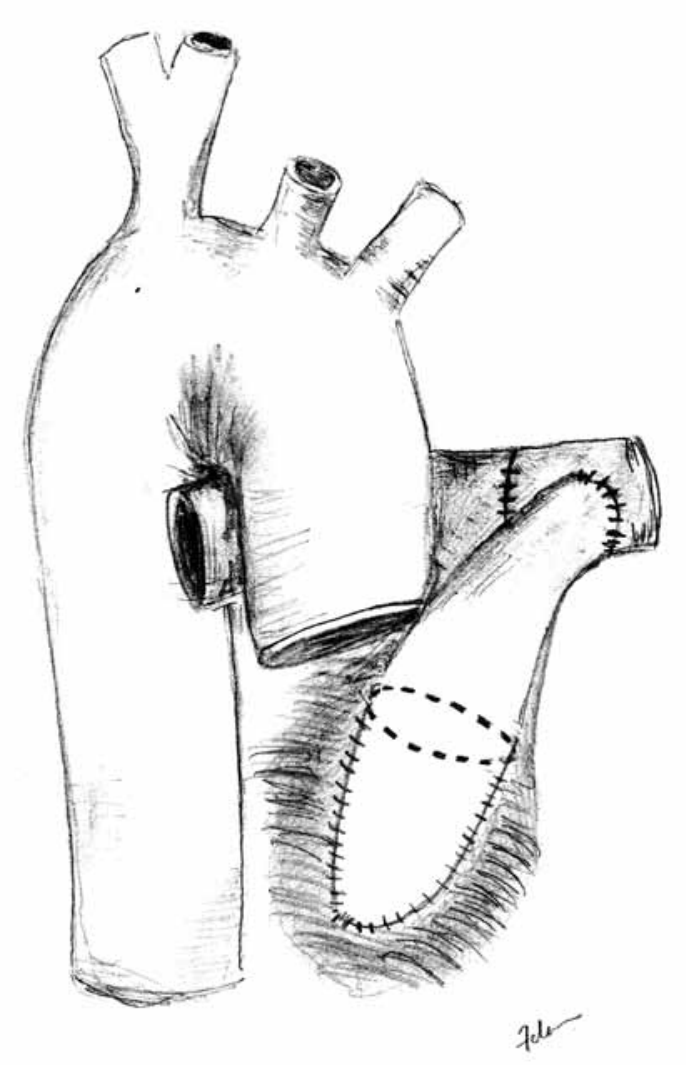

Fig. 2. Postoperative diagram after an anatomic repair with xenograft mono-cusp prosthesis and the recruitment of the anomalous pulmonary artery to the common bed of the pulmonary trunk

an anatomic ToF repair was done using an intracardiac Goretex patch for VSD closure and Contegra 'mono-cusp' transannular implantation as well as recruitment of the anomalous pulmonary artery to the common bed of the pulmonary trunk (Fig. 2). The early postoperative course was uneventful with successful extubation 4 hours postoperatively. The left pleura was drained because of exudative fluid accumulation on the second postoperative day. Control scheduled TTE and angio-CT scans 10 months later showed physiologic flow in the pulmonary trunk and a normal diameter of the LPA $(10 \mathrm{~mm})$, with adequate balanced perfusion of the beds of both pulmonary arteries. There was X-ray evidence of both sided upper pulmonary lobes regularly filled with some hypoperfusion of the left inferior lobe, with no further clinical consequences during 24 months of observation.

\section{Discussion}

Operative treatment of ToF in case of pulmonary artery discontinuation turns this standard surgical procedure into repair of more complex pathology, which can be accomplished with different therapeutic strategies [2]. In the present case, during the first hospitalization an emergency BT shunt was done and a month later total correction of the ToF was performed with reimplantation of the left pulmonary artery (the LPA originated from the Kommerell diverticulum via the PDA) to the pulmonary trunk [3]. In 
this patient classic BT was initially performed in the setting of cyanosis with only slight improvement in arterial saturation [3]. Because of the unclear pathophysiology we decided to perform cardiac catheterization, which revealed the right-sided aortic arch and Kommerell's diverticulum with PDA as the only blood supply to the obstructed LPA [4]. Ostial stenosis of the LPA was successfully percutaneously dilated with a balloon and finally total repair of the ToF was performed with pulmonary artery reconstruction [5].

Anomalies of pulmonary arteries do not preclude correction of ToF, unless there is a suprasystemic blood flow from an aortic source. In the case presented here, we performed a regular palliative treatment in a child referred from pediatric cardiology in an emergency setting. The shunt was done to the dominating pulmonary artery immediately after initial TTE [3]. After the symptoms of right sided pulmonary overflow (hydrothorax) we focused interest on unbalanced pulmonary perfusion [6]. Extremely helpful were interventional diagnostics and balloon dilatation of the stenosed PDA supplying the LPA, before the decision not to delay an anatomic correction. That was the argument to avoid direct stent implantation to the PDA, which seemed additionally risky in a one-year-old cyanotic child [5]. The option of simultaneous intracardiac defect correction with pulmonary artery bed reconstruction was in our opinion more efficient than off pump LPA implantation to the pulmonary trunk [3]. A reasonable argument was that primary recruitment of pulmonary arteries should create optimal conditions for later complete ToF repair, according to our institutional experience $[7,8]$. We believe that early diagnosis of discontinuous pulmonary artery would be crucial for choosing the optimal operative strategy, although our patient was referred to the institution as an emergency case, at the given age $[9,10]$. According to surgical technique limitations we performed the anastomosis in the margins of the natural LPA and main pulmonary artery (MPA) tissue to avoid implantation to the RV-PA conduit, because of potentially higher risk of secondary occlusion $[3,11]$.

\section{Conclusions}

We conclude that early diagnosis of discontinuous pulmonary artery is crucial for choosing the optimal operative strategy. In our opinion, simultaneous anatomic intracardiac correction with direct pulmonary reconstruction seems reasonable and effective, particularly when the result is achieved after joint efforts of cardiac surgery and interventional cardiology.

\section{Disclosure}

The authors report no conflict of interest.

\section{References}

1. Haponiuk I, Paczkowski K, Chojnicki M, Jaworski R, Steffens M, Juscinski J, Gierat-Haponiuk K, Zielinski J. Reconstruction of the left-sided brachiocepalic trunk after vascular ring operation in left-handed child with Kommerell's diverticulum. Postep Kardiol Inter 2013; 9: 146-149.

2. Stamm C, Friehs I, Zurakowski D, Scheule AM, Moran AM, Lock JE, Mayer JE, del Nido PL, Jonas RA. Outcome after reconstruction of discontinuous pulmonary arteries. J Thorac Cardiovasc Surg 2002; 123: 246-257.

3. Barbero-Marcial M, Atik E, Baucia JA, Pradel HO, Macruz R, Jatene AD. Reconstruction of stenotic or nonconfluent pulmonary arteries simultaneously with a Blalock-Taussig shunt. J Thorac Cardiovasc Surg 1988; 95: 82-89.

4. Carretero J, Rissech M, Mortera C, Mayol J, Caffarena J, Prada F. Aortic origin of the left pulmonary artery in an infant with Fallots tetralogy. Rev Esp Cardiol 2005; 58: 1124-1126.

5. Santoro G, Bigazzi MC, Palladino MT, Russo MG, Carozza M, Calabro R. Transcatheter palliation of tetralogy of fallot with pulmonary artery discontinuity. Tex Heart Institute J 2005; 32: 102-104.

6. Cheng W, Xiao Y, Zhong Q, Wen R. Anomalous origin of left pulmonary artery branch from the aorta with Fallots tetralogy. J Thorac Cardiovascular Surg 2008; 56: 432-434.

7. Haponiuk I, Chojnicki M, Steffens M, Jaworski R, Szofer-Sendrowska A, Juscinski J, Kwasniak E, Paczkowski K, Zielinski J, Gierat-Haponiuk K. Miniinvasive interventional bridge to major surgical repair of critically aortic coarctation in a newborn with severe multiorgan failure. Videosurg Miniinv 2013, 8: 244-248.

8. Chojnicki M, Haponiuk I, Jaworski R, Steffens M. Proximal ductus arteriosus stenosis after the hybrid stage I procedure in a newborn with hypoplastic left heart syndrome. Postep Kardiol Inter 2013, 9: 187-189.

9. Amaral F, Teixeira MA, Granzotti JA, Manso PH, Vincente WV. Anomalus origin of the left pulmonary artery from the ascending aorta. Successful surgical correction in an infant with Fallots tetralogy. Arg Bras Cardiol 2002: 79: 538-543.

10. Werner B, Tomik A, Golabek-Dylewska M, Godlewski K, Karolczak MA. Anomalous origin of the right pulmonary artery from the ascending aorta in 6-week-old infant. Kardiochir Torakochir Pol 2010, 7: 407-410.

11. Mozol K, Burczynski P, Haponiuk I. Late right pulmonary artery stenosis after arterial switch operation in mirror image dextrocardia and situs inversus totalis - report of a case. Kardiol Pol 2011; 69: 1066-1068. 